YAK 342.55

ББК 67.400 .7

DOI 10.22394/1682-2358-2017-3-147-152

D.I. Filatov, post-graduate student of the Service and Labor Law Department, Povolzhsky Institute of Management named after P.A. Stolypin, Branch of the Russian Presidential Academy of National Economy and Public Administration

\section{REFORMING THE SYSTEM \\ OF MUNICIPAL CONTROL IN THE RUSSIAN FEDERATION}

The key issues associated with the reforms for the implementation of municipal control in the Russian Federation are considered. The need to establish transparent mechanisms and specifications of municipal control that is a crucial task of the contemporary Russian state is proved.

Key words and word-combinations: local self-government, municipal control, reforms.
A.И. Фихатов, аспирант кафедрь служебного и трудового права Поволжского института управления имени П.А. Стольпина - филиала Российской академии народного хозяйства и государственной службы при Президенте РФ (email: lawfilatovdi@mail.ru)

\section{РЕФОРМИРОВАНИЕ СИСТЕМЫ МУНИЦИПААЬНОГО КОНТРО АЯ В РОССИЙСКОЙ ФЕАЕРАЦИИ}

Аннотациия. Рассматриваются ключевые проблемы, связанные с реализацией реформ на территории Российской Федерации по осуществлению муниципального контроля. Доказывается необходимость создания прозрачных механизмов и перечней муниципального контроля, являющихся ключевой задачей современного Российского государства.

Ключевые слова и словосочетания: местное самоуправление, муниципальный контроль, реформы.

B

2016 г. в России начамась реформа государственного и муниципального контроля (надзора). Она стартовала после издания нового правового акта: распоряжения Правительства Российской Федерации от 1 апремя 2016 г. № 559-р [1, с. 1] и Аорожной карты по совершенствованию контрольнонадзорной деятельности в Российской Федерации на 2016-2017 гг. [1, с. 2].

Отметим факт введения «надзорных каникум» на периол с 1 января 2016 г. по 
31 декабря 2018 г. в отношении юридических миџ, индивидуальных предпринимателей, отнесенных к субъектам малого предпринимательства, за исключением юридических миџ, индивидуальных предприниматемей, осуществляющих виды деятельности, перечень которых устанавливается Правительством Российской Федерации [2, ст. 26.1]. Такого рода мера дает возможность пересмотреть отношение к перспективам развития муниципального контроця как в условиях кризиса, так и к институту муниципального контроля в целом.

На современном этапе реформа государственного и муниџипального контроля (нацзора), безусловно, необходима. В то же время, несмотря на большой перечень изменений, обходятся стороной вопросы, касающиеся муниџипального контроля в Российской Федераџии.

К наиболее важным изменениям реформы относится внеАрение риск-ориентированного подхода при организации и осуществлении отдельных видов государственного контроля (надзора). Обусловливается это приведенными в дорожной карте статистическими данными, показывающими устойчивую тенденщию к снижению общего количества проверок [1, с. 7]. Среди нововведений, касающихся муниципального контроля в Российской Федерации, выделим изменения в Федеральном законе от 26 декабря 2008 г. № 294-Ф3 «О защите прав юридических миџ и индивидуальных предприниматемей при осуществлении государственного контроля (надзора) и муниџипального контроця» и добавление ст. 8.2 «Организаџия и проведение мероприятий, направленных на профилактику нарушений обязательных требований», и ст. 8.3 «Организация и проведение мероприятий по контролю без взаимодействия с юридическими миџами, индивидуальными предприниматемями». Аанные изменения относятся как к государственному контролю (надзору), так и к муниципальному контролю, оАнако можно привести примеры из истории современной России, когда реформы, непосредственно касавшиеся сферы государственного и муниџипального контроля (надзора), по большей части затрагивали госуАарственной контроль (надзор), а реформирование в сфере муниципального контроля осушествлялось по остаточному принципу.

«Первый подход к снаряду у нас успехом не увенчался. Надеемся, что второй подход к снаряду приведет к тому, что этот вес будет взят», - так помощник президента А. Белоусов 15 декабря 2015 г. прокомментировац реформу контрольно-надзорной деятельности, которая могла быть запущена, но теперь отможена в Аолгий ящик [3, с. 7]. Это обусловливанось сложностью и громоздкостью работ по оптимизации контрольно-надзорной деятельности в Российской Федерации.

Идея о введении новых методик осуществления муниџипального контромя кажется перспективной, но вопрос фактической реализации поправок к Федеральному закону от № 294-Ф3 остается неизученным. Органам местного самоуправления, и без того достаточно перегруженным работой, необходимо реализовать практику применения нововведений. Сложность заключается в большом объеме работ, а также в отсутствии разграничений полномочий межАу федеральными органами власти и органами местного самоуправления, касающихся указанных поправок в федеральное законодательство. Таким об- 
разом, данный вопрос будет регулироваться большим количеством подзаконных актов, что приведет к перегруженности системы законодательства, выполняющего контрольно-надзорные функции.

Статья 8.2 «Организация и проведение мероприятий, направленных на профицактику нарушений обязательных требований» Федерацьного закона № 294-Ф3 предусматривает широкий перечень полномочий и требований как к органам государственной власти, так и к органам местного самоуправмения.

К числу наиболее важных полномочий органов местного самоуправления необходимо отнести следующие. Во-первых, обеспечение размещения на официальных сайтах дмя каждого вида, муниџипального контроля перечней нормативных правовых актов или их отдельных частей, содержащих обязательные требования, оџенка соблюдения которых явцяется предметом муниципального контроця, а также текстов соответствующих нормативных правовых актов.

Во-вторых, осуществление информирования юридических миџ, инАивиАуальных предпринимателей по вопросам соблюдения обязательных требований, в том числе посреАством разработки и опубликования руководств по соблюдению обязательных требований, проведения семинаров и конференций, разъяснительной работы в средствах массовой информации и иными способами. В случае изменения обязательных требований органы муниципацьного контроля также подготавцивают и распространяют комментарии о содержании новых нормативных правовых актов, устанавливающих обязательные требования, внесенных изменениях в Аействующие акты, сроках и порядке вступления их в действие, а также рекомендации о проведении необходимых организационных, технических мероприятий, направленных на внедрение и обеспечение соблюдения обязательных требований.

В-третьих, обеспечение регулярного (не реже одного раза в год) обобщения практики осуществления в соответствующей сфере деятельности муниципального контроля и размещение на официальных сайтах соответствующих обобщений, в том числе с указанием наиболее часто встречающихся случаев нарушений обязательных требований с рекомендациями в отношении мер, которые Аолжны приниматься юридическими Аицами, индивидуальными преАпринимателями в цемях недопущения таких нарушений; в четвертых, выдача предостережения о недопустимости нарушения обязательных требований в соответствии с ч. 5-7 ст. 8.2. Федерального закона № 294-Ф3, если иной порядок не установлен федеральным законом.

ААминистративные реформы, проводившиеся на протяжении более Авух десятилетий, призваны были стабилизировать аппарат государственного управления, определить и разграничить полномочия в сфере контрольно-наАзорных функций государственных и муниципальных органов, определить регмаменты данного взаимодействия касательно всех возможных аспектов. На практике же основная доля внимания со стороны реформаторов удемялась органам государственной власти и органам субъектов РФ.

ААминистративная реформа явцяется инструментом решения не столько проблем государственной системы, сколько экономики в целом, так как инер- 
тность аАминистративной системы и некачественное управление в условиях высокой степени институџионализации отношений государства и общества превращаются в один из основных ограничителей экономического роста [4, с. 25] .

Субъектам РФ было предоставлено право перераспределять полномочия межАу органами местного самоуправцения и органами государственной вцасти субъекта РФ и определять перечень вопросов местного значения сельских поселений. Такой подход был призван разграничить вопросы ведения межАу разцичными уровнями муниципальных образований, и в том числе усовершенствовать муниципальный контроль, однако на практике сельские посемения (как и большинство муниципальных образований в целом) не имеют Аостаточного объема финансовых и иных ресурсов Аля организации качественного муниципацьного контроця.

В дорожной карте реформы государственного и муниципального контроця также выделена необходимость создания комплексного информационно-коммуникационного обеспечения контрольно-надзорной деятельности в Российской Федерации. Так, организация эффективной системы оџенки рисков и управления ими предусматривает проведение анациза большого объема данных, в частности, о характеристиках подконтрольных субъектов и результатах их предылущих проверок, что принщипиально невозможно без внедрения современных информационно-коммуникационных технологий. В связи с этим планируется создание федеральной государственной информаџионной системы «Федеральный реестр государственных и муниципальных услуг (функций)», еАиного реестра проверок, федеральной государственной информационной системы «ЕАиный портал государственных и муниџипальных услуг (функщий)», государственной автоматизированной информаџионной системы «Управление», ведомственных государственных информаџионных систем контрольно-надзорных органов, используемых дия информаџионно-аналитического обеспечения контрольно-надзорной деятельности, а также дия обеспечения межведомственного взаимодействия при осуществлении контрольно-надзорной Аеятельности.

По нашему мнению, данная система не сможет вобрать в себя все функции по стандартизации муниципального контроля в Российской Федераџии ввиАу своей громоздкости, учитывая специфику местного самоуправления на современном этапе развития Российской Федерации. В связи с этим необходимо усовершенствовать законодательство о муниџипальном контроле с учетом сложившейся в современной практике применения данной функции. Разрешение на законоАательном уровне может включать в себя перечень следующих вопросов: обязательность применения функции муниципального контроля органами местного самоуправления; оџенку эффективности деятельности органов местного самоуправления; наделенных контрольными полномочиями; унификацию Аеятельности муниципального контроля на территории Российской Федерации; информационное обеспечение деятельности муниципального контроля и Аругие.

Ао сих пор еАиной системы и перечня видов муниципацьного контроця в законодательстве Российской Федераџии нет, его анализ позволяет выявить около полутора десятков видов муниципацьного контроця, реацизуемых в рам- 
ках собственных полномочий органов местного самоуправления. Виды контрольных полномочий органов местного самоуправления, закрепленных в федеральном законодательстве, могут быть подразделены на два вида: собственные и делегированные [5, с. 4].

К собственным полномочиям традиционно относятся следующие виды муниципального контроля: земельный; жилищный; контроль в области использования и охраны особо охраняемых природных территорий местного значения; контроль за сохранностью автомобильных дорог местного значения; месной; контроль за соблюдением законодательства в области розничной продажи алкогольной продукции. К числу делегированных полномочий можно отнести, например, $и$ цензионный контроль за розничной продажей алкогольной продукции.

Нельзя обходить стороной и внутренний муниџипальный контроль как неотъемлемую часть муниципального управления в целом. Внутренний контроль в муниципальном образовании подразделяется на представительный, осуществмяемый представительными органами и создаваемыми контрольными органами муниципального образования [2, ст. 35] и административный, осуществАяемый руководством администраџии и ее структурными подраздемениями.

Ведутся дискуссии о таких «специфических» видах муниципального контроля, как контроль населения за органами местного самоуправления [2, ст. 70; 71] и контроль советов мунищипальных образований, осуществмяющийся в рамках требований Федерального закона от 12 января 1996 г. № 7-ФЗ «О некоммерческих организациях», применяемыми к ассоџиациям [2, ст. 8]. Аля этих видов муниципального контроля не находится практического применения, при этом потенциал данных правовых механизмов достаточно велик. По нашему мнению, виной этому является отсутствие четких законодательных норм, регулирующих данный вопрос, а также отсутствие правоприменительной практики.

В соответствии с законодательством полномочия органов местного самоуправления, осуществляющих мунищипальный контроль, и органов местного самоуправления, уполномоченных на осушествление муниципального контромя органами субъектов РФ, установление их организационной структуры, полномочий, функций и порядка их деятельности и определение перечня должностных миц указанных уполномоченных органов местного самоуправления и их полномочий осуществцяются в соответствии с уставом муниџипального образования и иным муниципальным правовым актом.

Органы местного самоуправления постоянно взаимодействуют с органами государственной власти. Авойственный характер муниџипальной деятельности обусловливает необходимость взаимодействия органов местного самоуправления с органами государственной власти не только при реализаџии отдельных государственных полномочий, которыми они могут надемяться, но и в поряАке оказания содействия государственным органам в выполнении их задач и функций на местном уровне. ОАнако единого полноценного механизма этого взаимодействия до сих пор не создано.

Залогом дальнейшего успешного развития федеративного государства явцяется согласованная деятельность всех уровней власти. Разграничение компетенций между федеральными, регионамьными и муниципальными органа- 
ми власти Аолжно осуществцяться с учетом особенностей соответствующей территории (географических, экономических, демографических, этнических и Аругих), чтобы конкретные полномочия возцагались на органы власти, способные максимально эффективно их осуществлять [6, с. 3] .

Наиболее ярким примером несовершенства данной системы является доклаА Минэкономразвития России «О состоянии системы муниципального контроля в Российской Федераџии» от 6 Аекабря 2011 г., Аемонстрирующий состояние местного самоуправления относительно функщии муниџипального контроля [5, с. 6]. Аокмады за 2015-2016 гг. свидетельствуют, что состояние муниципального контроця на территории Российской Федераџии находится в глубокой стагнации. В большинстве муниџипальных образований контроль осуществляется только по двум видам. Наиболее популярными видами муниципального контроля явцяются земельный, контроль ЖКХ, контроль за состоянием Аорог местного значения и месной контроль.

Муниципацьный контроль представцяет собой сложный, громозАкий и непоцноценный механизм соблюдения законности и прав по местному самоуправлению в Российской Федерации в целом и, как слеАствие, сложен в применении. Отметим также отсутствие стандартов реацизации муниципального контроця, а объем реформ, непосредственно коснувшихся местного самоуправления и муниципального контроля в период современной России, очень велик, что повлекцо за собой невозможность адекватной реализации функџии муниципального контромя в Российской Федерации.

Требуется создание прозрачных механизмов и перечней муниципального контроця является кцючевой задачей современного Российского государства, а также комплексные исследования Аанного вопроса и применения их результатов на законодательном уровне.

Немаловажен вопрос и о практической реализаци нововведений в сфере муниципального контроця на разцичных этапах реформирования в области местного самоуправления. Комплексный анализ указанных реформ позволит увидеть четкую картину современного состояния сферы муниципального контроля в Российской Федерации.

\section{Библиографический список}

1. Распоряжение Правительства Российской Федерации от 1 апреля 2016 г. № 559-p. URL: https://government.consultant.ru/documents/3708979

2. Об общих принципах организации местного самоуправления в Российской Федерации: Федер. закон от 6 окт. 2003 г. № 131 (с изм. от 28 дек. 2016 г.) // СЗ РФ. 2003. № 40. Ст. 3822.

3. Милюкова Я., Нетреба П. Полгода на доделку. URL: http://www.rbc.ru/newspaper/2015/ 12/16/56bc8a059a7947299f72b773

4. Гаталов Е.Н. Проблемы современной административно-государственной реформы в России // Власть. 2009. № 3. С. 21-32.

5. Муниципальный контроль в Российской Федерации: аналитический доклад / Министерство экономического развития Российской Федерации. М., 2011.

6. Корж Е.Г., Макаренко С.Н. Взаимодействие органов государственной власти с органами местного самоуправления // Известия Южного федерального университета. Технические науки. 2013. № 6 (143). С. 196-201. 